\title{
PENGARUH TINDAKAN CHEMOTERAPHY TERHADAP PENINGKATAN HARAPAN HIDUP PASIEN CANCER MAMAE DI RSU IMELDA PEKERJA INDONESIA MEDAN
}

\author{
Noradina \\ Universitas Imelda Medan, Jl. Bilal No. 52 Kelurahan Pulo Brayan Darat I Kecamatan Medan Timur, \\ Medan - Sumatera Utara. \\ Email : dinanora@gmail.com
}

\begin{abstract}
ABSTRAK
Tumor ganas yang berkembang dalam jaringan mammae, yang diduga berpengaruh atau berdampak pada kualitas hidup penderitanya disebut dengan Carcinoma mammae (ca mammae). Akibat dari ca mammae Pengaruh kejiwaan atau yang kuat akibat ca mammae dapat berdampak negatif pada kehidupan penderita, terutama pada penderita post mastectomy. Tindakan untuk menangani atau mengatasi penyakit ca mammae bukan hanya sekedar untuk menyelamatkan nyawa atau sebuah mammae, akan tetapi juga merupakan salah satu usaha pencapaian kualitas hidup terbaik. Oleh karena itu perlu diadakan penelitian Gambaran Kualitas Hidup Penderita Ca Mammae Post Mastectomy di CISC dan BCS Tahun 2010. Yang menjadi tujuan dari penelitian ini adalah untuk mengetahui suatu gambaran kualitas hidup para penderita ca mammae post mastectomy yang dihubungkan dengan kondisi psikologik, kehidupan sosial dan tanggapan keluarga. Metode penelitian ini adalah deskriptif murni dengan rancangan cross sectional. Instrumen penelitian berupa kuesioner yang berisi 37 pertanyaan. Subjek dalam penelitian ini saya ambil adalah data penderitah penyakit ca mammae post mastectomy di komunitas kanker CISC (Cancer Information and Support Center) Jakarta dan BCS (Bandung Cancer Society), teknik penentuan sampel dalam penelitian ini adalah purposive sampling. Dimana tindakan mastectomy tidak menyebabkan adanya perubahan kualitas hidup pada penderita ca mammae yang dinilai dari segi kondisi psikologik, kehidupan sosial, dan tanggapan keluarga. Dari hasil pembahasan maka kesimpulan dari penelitian ini adalah tindakan mastectomy tidak menyebabkan adanya perubahan kualitas hidup pada penderita ca mammae.
\end{abstract}

Kata kunci : Ca. Mammae, Post Mastectomy, Kualitas Hidup.

\section{ABSTRACT}

Malignant tumors that develop in mammary tissue, which are thought to influence or affect the quality of life of sufferers, are called Carcinoma mammary (ca mammary). Consequences of Ca Mammae Psychiatric effects or a strong effect of Ca Mammae can have a negative impact on the lives of sufferers, especially in post mastectomy sufferers. The action to deal with or deal with ca mammary disease is not just to save lives or a mammary, but it is also an effort to achieve the best quality of life. Therefore, it is necessary to conduct a study on the Quality of Life of Ca Mammae Post Mastectomy Patients in CISC and BCS in 2010. The purpose of this study is to find a picture of the quality of life of post-mastectomy patients with cammary conditions associated with psychological conditions, social life and responses family. This research method is purely descriptive with cross sectional design. The research instrument was in the form of a questionnaire containing 37 questions. The subject in this study I took was the data of ca mammary disease post mastectomy in the CISC (Cancer Information and Support Center) Jakarta and BCS (Bandung Cancer Society) cancer community, the sampling technique in this study was purposive sampling. Where the mastectomy does not cause a change in the quality of life in patients with breast cancer which is assessed in terms of psychological conditions, social life, and family response. From the results of the discussion the conclusion of this study is that the act of mastectomy does not cause changes in the quality of life in patients with ca mammary.

Keywords: Ca. Mammae, Post Mastectomy, Quality of Life.

\section{PENDAHULUAN}

Cancer mamae merupakan suatu kondisi dimana sel telah kehilangan pengendalian dan mekanisme normalnya, sehingga terjadi pertumbuhan yang tidak normal cepat dan tidak terkendali yang terjadi pada jaringan payudara. Kanker payudara adalah ketika sejumlah sel di dalam payudara tumbuh dan 
berkembang dengan tidak terkendali yang menyusup ke jaringan tubuh normal dan menekankan jaringan tumbuh normal. Kanker payudara (Carcinoma Mammae) merupakan salah satu kanker yang sangat ditakuti oleh kaum wanita, setelah kanker serviks. (Chytia dan Diananda 2009).

Berdasarkan data WHO 2008 sebanyak 23\% kanker pada wanita adalah cancer mamae. Estimasi Globocan, Internasional Agency for Research on Cancer (IARC). Tahun 2012, insidens kanker payudara sebesar 40 per 100.000 perempuan, kanker leher rahim 17 per 100.000 perempuan (Depkes RI, 2014). Angka kejadian kanker payudara di Amerika Serikat tahun 2013 ada sebanyak 296.890 kasus. (Alteri Rick et all, 2013). Di Indonesia prevalensi penyakit juga cukup tinggi. Berdasarkan data Riset Kesehatan Dasar (Riskesdas) tahun 2013, kanker tertinggi di Indonesia pada perempuan adalah kanker payudara. Data dari Jakarta Breast Center mengkhususkan diri untuk penanganan keluhan pada payudara menunjukkan bahwa dari 2.495 pasien yang datang pada tahun 2001 dan 2002 ternyata 79 persen menderita tumor jinak dan hanya $14 \%$ menderita kanker. Penyebab terjadinya kanker payudara hingga saat ini belum diketahui, namun Menurut Hawari (2004) banyak faktor resiko terjadinya kanker payudara diantaranya wanita berumur 25 tahun keatas, wanita tidak kawin.

Menurut data informasi Rumah Sakit Umum Imelda Medan pasien yang mengalami cancer Januari-Desember 2017 sebanyak 190 pasien. Data yang diperoleh dari ruangan kemoterapi adalah penderita cancer yang paling banyak adalah cancer Nasopharyngeal Carcinoma (NPC) sebanyak 87 pasien, cancer ovarium sebanyak 23 pasien, dan cancer tyroid hanya 17 pasien dan pasien cancer mamae hanya 63 pasien. Dan pada pasien cancer mamae kemoterapi dilakukan selama 4 siklus baik stadium 1 maupun stadium lanjut dengan harapan hidup 85-95 \% jika masih dalam stadium 1.

Kemoterapi merupakan pengobatan terapi sistemik disebut juga terapi melalui infus sehingga obat dapat masuk ke seluruh sistem di tubuh penderita penyakit kanker dan yang paling sering digunakan. Kemoterapi dapat juga bersifat sebagai terapi utama yaitu bila kanker sudah menyebar dan secara lokal pun sudah tidak dapat dilakukan operasi lagi. Untuk oral biasanya diberikan selama dua minggu, istirahat 1 minggu, dan kalau lewat infus 6 kali kemo jaraknya 3 minggu untuk full dosse. Saat ini sudah berkembang cara kemoterapi yang disebut "Neo Adjuvant" dengan cara ini kemoterapi sebagian diberikan sebelum operasi (biasanya 3 kali siklus) dengan tujuan mengecilkan kanker yang besar sehingga operasi dapat dilakukan dengan baik yaitu mengangkat seluruh tumor.

Kemoterapi telah digunakan sejak tahun 1950 tahun biasa diberikan sebelum dan sesudah pembedahan. Kadang disertai dengan terapi radiasi yang bertujuan untuk membasmi seluruh sel kanker sampai ke akar akarnya sampai tidak terjangkau pisau bedah, paling tidak untuk mengontrol sel sel kanker agar tidak menyebar luas. Efek samping kemoterapi timbul akrena obat obatan kemoterapi yang sangat kuat, dan tidak hanya membunuh sel kanker, tetapi menyerang sel sel sehat, terutama membunuh sel sel yang membelah dengan cepat. Karena itu efek samping kemoterapi muncul pada sel sel yang membelah dengan cepat (Dinkes, RI 2008).

Harapan hidup untuk cancer mamae menurut British journal of cancer menunjukkan bahwa cancer payudara tingkat kelangsungan hidup 5 tahun setelah menjalani kemoterapi. The American cancer society (ACS) menyatakan bahwa kelangsungan hidup lima tahun setelah diagnosa pada cancer mamae stadium 4 adalah 22 persen. Tingkat harapan hidup menurut Notoadmojo (2003) dengan bekerja seseorang dapat berbuat sesuatu yang bernilai, bermanfaat, dan memperolah pengalaman. Seseorang yang bekerja memiliki banyak informasi pengetahuan cukup sehingga pasien ca mamae angka harapan hidup semakin meningkat.

Setelah diteliti bahwa seluruh pasien penderita Ca mamae stadium III meninggal, oleh karena itu diharapkan kepada semua wanita dapat melakukan deteksi dini ca mamae agar tidak terjadi peningkatan stadium yang lebih lanjut. Setiap penderita ca mamae termotivasi untuk melakuakn pengobatan meskipun harapan hidupnya pendek, karena pengobatan terbukti memperpanjang harapan hidup hingga 10,75 
kali. Data Riskesdas 2007 menyebutkan prevalensi kejadian tumor atau kanker di indonesia sebesar 4,3 per 100 penduduk dengan angka harapan hidupnya adalah $85 \%-95 \%$ jika penyakit ini ditemukan sendiri oleh penderita. Angka kelangsungan hidup 5 tahun pada penderita ca mamae yang telah menjalani pengobatan yang sesuai dengan standard sebesar mendekati 95\% (untuk stadium I), $88 \%$ (untuk stadium II), $36 \%$ (untuk stadium III) dan 7\% (untuk stadium IV).

Menurut American Cancer Association, kemungkinan wanita terkena kanker payudara itu satu banding delapan orang atau $12 \%$. Adapun beberapa gejala kanker payudara adalah:

a. Ditemukanya benjolan pada payudara. Menurut American Cancer Society, gejala awal yang signifikan dan sering dialami wanita ialah benjolan tidak biasa yang ditemukan pada payudara. Benjolan itu biasanya ditandai dengan rasa sakit bila dipegang atau ditekan.

b. Gejala perubahan bentuk payudara terlihat dari berubahnya ukuran dan bentuk pada putting. Dimana gejala itu awalnya ditandai dengan permukaan merah, kemudian perlahan kulit mengerut seperti kulit jeruk. Ada pula dalam kasus lain warna payudaranya berubah orange.

c. Puting mengeluarkan cairan pada puting seringkali mengeluarkan cairan (nipple discharge) seperti darah tetapi juga terkadang juga berwarna kuning kehijau hijauan berupa nanah.

d. Pembengkakan pada payudara gejala kanker payudara juga ditanadai dengan pembengkakan payudara tanpa ada benjolan, yang merupakan gejala umumnya. Bahkan, kadang kadang salah satu payudara pembuluh darah jadi lebih terlihat.

\section{Harapan Hidup Pada pasien Cancer mamae}

Saat ini banyak obat anti kanker yang telah diteliti untuk membantu $50 \%$ pasien yang telah mengalami kanker tahap akhir dengan tujuan memperbaiki harapan hidup. Walaupun hanya sedikit yang terbukti mampu memperpanjang harapan hidup pada pasien, diantaranya adalah kombinasi trastuzumamb dengan capecitabine. Fokus terapi pada kanker tahap akhir bersifat paliatif (mengurangi rasa sakit). Dokter berupaya untuk memperpanjang serta memperbaiki kualitas hidup pasien melalui terapi kemoterapi.

Dokter subspesialis onkologi ginekologi Andrijono mangatakakan terapi ini dapat meningkatkan harapan hidup pasien kanker, yaitu 27 persen tanpa mengalami perburukan. Terapi ini bisa memperpanjang hidup penderita kanker, efek sampingnya juga relatif lebih rendah. Tingkat kelangsungan hidup selama lima tahun setelah diagnosa pada pasien kanker payudara stadium 4 adalah 22 persen. Persentase ini jauh lebih rendah dari pada stadium awal, pada stadium 3 lima tahun tingkat kelangsungan hidup 72 persen (American Cancer Society).

Penelitian sebelumnya yang berjudul Gambaran Perubahan Body Image Pada Wanita Yang Mengalami Ca.Mamae Dengan Tindakan Chemoterphy Di Rumah Sakit Umum Imelda Pekerja Indonesia (RSU IPI) Medan menyatakan apabila pengetahuan atau pendidikan yang cukup memadai secara teoritis dan objektif disebabkan sikap penderita masih kurang menerima informasi tentang pendidikan kesehatan perubahan Body Image bagi wanita penderita $\mathrm{Ca}$ Mamae dengan tindakan Chemotherapy. Disini jugalah pentingnya peranan tenaga kesehatan untuk meningkatkan pengetahuan penderita dan masyarakat pada umumnya untuk dapat penanggulangan dalam mencegah perubahan yang buruk pada penderita $\mathrm{Ca}$ Mamae, salah satunya pemberian penyuluhan tentang perubahan Body Image pada penderita $\mathrm{Ca}$ Mamae dengan tindakan Chemotherapy (Noradina \& Zainofrianto, 2019).

Penelitian yang lain berjudul Pengaruh Activity Daily Livingtraining Terhadap Kemandirian Pasien Kanker Payudara Di Murni Teguh Memorial Hospital menyatakan peningkatan kemampuan responden melakukan Activity Daily Living's di rumah. Program latihan ini dapat menjadi masukan kepada perawat untuk memberikan program ini melalui home care (Hasibuan, 2018).

Tingkat harapan hidup bagi pasien kanker payudara didasarkan pada studi dari banyak pasien dengan kondisi tersebut. Statistik ini dapat memprediksi kesehatan masa depan dan umur. Harapan hidup 
penderita kanker payudara dapat dipengaruhi oleh: usia, kesehatan, reseptor hormon pada sel kanker, jenis jaringan yang telah terpengaruh kanker, sikap dan pandangan.

\section{METODE}

Jenis penelitian yang digunakan adalah survey deskritif dengan menggunakan data primer, yang dikumpulkan melalui kuisioner. Untuk mengetahui pengaruh pemberian tindakan chemoterapi terhadap peningkatan harapan hidup pada pasien ca mamae di Rumah Sakit Umum Imelda Medan Pekerja Indonesia (RSU IPI) Medan. Lokasi penelitian dilakukan di Rumah Sakit Umum Imelda Medan Pekerja Indonesia (RSU IPI) Medan. Penelitian ini pada bulan Mei - Juni Periode Tahun 2017. Populasi dalam penelitian ini adalah pasien yang menderita penyakit. Ca Mamae di Rumah Sakit Umum Imelda Medan Pekerja Indonesia (RSU IPI) Medan. Dan seluruh populasi berjumlah 32 orang.

\section{Sampel}

Cara pengambilan sampel dilakukan dengan menggunakan metode total sampling yang merupakan pengambilan sampel yang dilakukan dengan menggunakan sampel atau responden secara keseluruhan yaitu:

$$
\begin{aligned}
\mathrm{n}= & \frac{\mathrm{N}}{1+\mathrm{N}\left(\mathrm{d}^{2}\right)} \\
& =\frac{170}{1+171\left(0,05^{2}\right)} \\
& =32
\end{aligned}
$$

Keterangan :

$\mathrm{N}$ : Besar populasi

$\mathrm{n}$ : Besar sampel

$\mathrm{d}$ : Tingkat kepercayaan yang diinginkan.

Besar sampel pada penelitian ini adalah seluruh populasi yang ada yang disesuaikan dengan kriteria inklusi (kriteria layak diteliti) berjumlah 32 pasien di Rumah Sakit Umum Imelda Medan Pekerja Indonesia (RSU IPI) Medan.

\section{Variabel Pengetahuan}

Pengukuran untuk variabel pengetahuan menggunakan skala Guttman yaitu jawaban responden salah bernilai 0, dan apabila jawaban responden benar bernilai 1, kemudian di formulasikan menggunakan rumus Range (kelas) untuk setiap interval jawaban menggunakan rumus:

Range $=\underline{\text { Skor maximal }- \text { Skor minimal }}$

$$
\text { Sedangkan untuk mengetahui }
$$

persentase jawaban responden melalui kriteria responden menggunakan rumus Determinan oleh Setiadi (2007) yaitu :

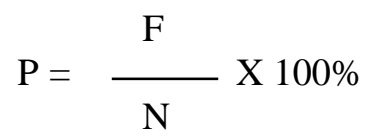

Keterangan :

$$
\begin{array}{ll}
\mathrm{P} & \text { : Persentase } \\
\mathrm{F} & \text { : Jumlah jawaban benar } \\
\mathrm{N} & \text { : Jumlah soal }
\end{array}
$$

\section{HASIL}

Dari hasil penelitian yang berjudul "Pengaruh pemberian tindakan chemoteraphy terhadap peningkatan harapan hidup pada pasien cancer mamae di Rumah Sakit Umum Imelda Pekerja Indonesia (RSU IPI) Medan Tahun 2018“ hasil yang disajikan pada tabel dibawah ini:

\section{Kriteria Responden}

Tabel 1. Distribusi Frekuensi Pengaruh Pemberian Tindakan Cemoteraphy Terhadap Peningkatan Hidup Pada Pasien Cancer Mamae di RSU Imelda Medan 2018

\begin{tabular}{cccc}
\hline No & Pengetahuan & Frekuensi & $\mathbf{\%}$ \\
\hline 1. & Baik & 10 & $6,3 \%$ \\
\hline 2. & Cukup & 8 & $37,5 \%$ \\
\hline 3. & Kurang & 14 & $56,2 \%$ \\
\hline & Jumlah & $\mathbf{3 2}$ & $\mathbf{1 0 0}$
\end{tabular}

Berdasarkan tabel 1 distribusi frekuensi di atas, tindakan chemoteraphy terhadap peningkatan hidup pada pasien cancer mamae dapat dilihat bahwa dari 32 responden, mayoritas responden berpengetahuan kurang sebanyak 10 responden $(56,2 \%)$ dan minoritas responden berpengetahuan cukup sebanyak 8 responden $(37,5 \%)$. 
Pengetahuan Responden Berdasarkan Umur

Tabel 2. Distribusi Frekuensi Pengaruh Pemberian Tindakan Chemoteraphy Terhadap

Peningkatan Hidup Pada Pasien Cancer Mamae di RSU Imelda Medan 2018

\begin{tabular}{|c|c|c|c|c|c|c|c|c|c|}
\hline \multirow{3}{*}{ No } & \multirow{3}{*}{ Umur } & \multicolumn{6}{|c|}{ Pengetahuan } & \multirow{2}{*}{\multicolumn{2}{|c|}{ Total }} \\
\hline & & \multicolumn{2}{|c|}{ Baik } & \multicolumn{2}{|c|}{ Cukup } & \multicolumn{2}{|c|}{ Kurang } & & \\
\hline & & $\mathbf{F}$ & $\%$ & $\mathbf{F}$ & $\%$ & $\mathbf{F}$ & $\%$ & $\mathbf{F}$ & $\%$ \\
\hline 1. & $<20$ Tahun & 0 & 0 & 4 & 12,5 & 5 & 15,6 & 9 & 6,25 \\
\hline 2. & 20-35 Tahun & 0 & 0 & 6 & 18,7 & 12 & 37,5 & 18 & 56,25 \\
\hline 3. & $>35$ Tahun & 2 & 6,25 & 2 & 6,25 & 1 & 3,1 & 5 & 12,2 \\
\hline & Jumlah & 10 & 6,25 & 8 & 37,5 & 14 & 56,25 & 32 & 100 \\
\hline
\end{tabular}

Dari hasil tabel 2 di atas dapat dilihat kurang sebanyak 14 responden (37,5\%) yaitu bahwa tindakan chemoteraphy terhadap peningkatan hidup pada pasien cancer mamae mayoritas responden berpengetahuan berumur 20-35 tahun. Dan minoritas yang berpengetahuan baik sebanyak 10 responden $(6,25 \%)$ yaitu berumur 35 tahun.

\section{Pengetahuan Responden Berdasarkan Sumber Informasi}

Tabel 3. Distribusi Frekuensi Pengaruh Pemberian Tindakan Chemoteraphy Terhadap Peningkatan Hidup Pada Pasien Cancer Mamae di RSU Imelda Medan 2018

\begin{tabular}{|c|c|c|c|c|c|c|c|c|c|}
\hline \multirow{3}{*}{ No } & \multirow{3}{*}{ Sumber Informasi } & \multicolumn{6}{|c|}{ Pengetahuan } & \multirow{2}{*}{\multicolumn{2}{|c|}{ Total }} \\
\hline & & \multicolumn{2}{|c|}{ Baik } & \multicolumn{2}{|c|}{ Cukup } & \multicolumn{2}{|c|}{ Kurang } & & \\
\hline & & $\mathrm{F}$ & $\%$ & $\mathrm{~F}$ & $\%$ & $\mathrm{~F}$ & $\%$ & $\mathrm{~F}$ & $\%$ \\
\hline 1. & Media Massa & 0 & 0 & 4 & 12,5 & 6 & 18,7 & 10 & 31,2 \\
\hline 2. & Tenaga Kesehatan & 2 & 6,25 & 5 & 15,6 & 0 & 0 & 7 & 21,9 \\
\hline 3. & Masyarakat & 0 & 0 & 3 & 9,4 & 12 & 37,5 & 15 & 46,9 \\
\hline & Jumlah & 10 & 6,25 & 8 & $\mathbf{3 7 , 5}$ & 14 & 56,25 & 39 & 100 \\
\hline
\end{tabular}

Dari hasil tabel di atas dapat di lihat bahwa tindakan chemoteraphy terhadap peningkatan hidup pada pasien cancer mamae dari 32 responden mayoritas responden berpengetahuan kurang sebanyak 14 responden $(37,5 \%)$ yang mendapat sumber informasi dari masyarakat. Minoritas responden yang berpengetahuan baik sebanyak 10 responden $(6,25 \%)$ yang mendapat sumber informasi dari tenaga kesehatan. Dari hasil penelitian maka bahwa tindakan chemoteraphy terhadap peningkatan hidup pada pasien cancer mamae pembahasannya sabagai berikut:

\section{Pengetahuan Responden Berdasarkan Paritas}

Tabel 4. Distribusi Frekuensi Pengaruh Pemberian Tindakan Chemoteraphy Terhadap Peningkatan Hidup Pada Pasien Cancer Mamae di RSU Imelda Medan 2018

\begin{tabular}{|c|c|c|c|c|c|c|c|c|c|}
\hline \multirow{3}{*}{ No } & \multirow{3}{*}{ Paritas } & \multicolumn{6}{|c|}{ Pengetahuan } & \multirow{2}{*}{\multicolumn{2}{|c|}{ Total }} \\
\hline & & \multicolumn{2}{|c|}{ Baik } & \multicolumn{2}{|c|}{ Cukup } & \multicolumn{2}{|c|}{ Kurang } & & \\
\hline & & $\mathbf{F}$ & $\%$ & $\mathbf{F}$ & $\%$ & $\mathbf{F}$ & $\%$ & $\mathbf{F}$ & $\%$ \\
\hline 1. & Primipara & 0 & 0 & 1 & 3,1 & 5 & 15,5 & 6 & $\overline{18,6}$ \\
\hline 2. & Scundipara & 0 & 0 & 7 & 21,9 & 2 & 6,3 & 9 & 28,2 \\
\hline 3. & Multipara & 2 & 6,3 & 4 & 12,5 & 11 & 34,4 & 17 & 53,2 \\
\hline & Jumlah & $\mathbf{1 0}$ & 6,3 & 8 & 37,5 & 14 & 56,2 & 32 & 100 \\
\hline
\end{tabular}

Dari hasil tabel 4 di atas dapat di lihat bahwa Pengaruh pemberian terapi chemoteraphy di RSU Imelda Medan paritas dari 32 responden mayoritas responden berpengetahuan kurang sebanyak 14 responden $(34,4 \%)$ yaitu multipara. Minoritas berpengetahuan cukup sebanyak 8 responden $(3,1 \%)$ yaitu primipara.

\section{PEMBAHASAN}

Dari hasil penelitian tindakan chemoteraphy terhadap peningkatan hidup pada pasien cancer mamae maka pembahasannya sabagai berikut:

Berdasarkan hasil penelitian yang disajikan pada tabel 1 menunjukkan bahwa tindakan chemoteraphy terhadap peningkatan hidup pada pasien cancer mamae berdasarkan pengetahuan mayoritas responden berpengetahuan kurang sebanyak 14 responden $(56,2 \%)$ dan minoritas responden berpengetahuan cukup sebanyak 8 responden $(37,5 \%)$. Dalam hal ini peneliti menarik kesimpulan bahwa 
pengetahuan wanita tentang cancer mamae kurang baik.

Berdasarkan hasil penelitian yang disajikan pada tabel 2 menunjukkan bahwa tindakan chemoteraphy terhadap peningkatan hidup pada pasien cancer mamae dari 32 responden mayoritas responden berpengetahuan kurang sebanyak 14 responden $(37,5 \%)$ yaitu berumur 20-35 tahun. Dan minoritas yang berpengetahuan baik sebanyak 10 responden $(6,25 \%)$ yaitu berumur 35 tahun.

Menurut Nursalam, (2003) Umur adalah Orang yang lebih muda mempuyai daya ingat yang lebih kuat dan beraktivitas. Lebih tinggi dalam mencari dan mengenal suatu yang belum di ketahui dibandingkan dengan orang yang lebih tua. Disamping itu, kemampuan untuk meyerap pengetahuan baru lebih muda di lakukan pada umur yang lebih mudah karena otak berfungsi maksimal pada umur muda.

Menurut asumsi penulis, bahwa semakin cukup umur maka semakin tingkat juga pengetahuan seseorang dalam berfikir dan bekerja dari segi kepercayaan dari pada yang belum cukup tinggi kedewasaannya. Hal ini sebagian akibat pengalaman dan kematangan jiwanya.

Berdasarkan hasil penelitian yang disajikan pada tabel 3 menunjukkan bahwa dari tindakan chemoteraphy terhadap peningkatan hidup pada pasien cancer mamae dari 32 responden. mayoritas responden berpengetahuan kurang sebanyak 14 responden $(37,5 \%)$ yang mendapat sumber informasi dari masyarakat. Minoritas responden yang berpengetahuan baik sebanyak 10 responden $(6,25 \%)$ yang mendapat sumber informasi dari tenaga kesehatan.

Menurut Notoatmodjo (2007), sumber informasi adalah semua bentuk informasi kesehatan, biasanya berasal dari petugas kesehatan yang dilakukan oleh petugas kesehatan dengan cara cemara tentang kesehatan dan diskusi kesehatan tentang suatu penyakit. Menurut asumsi penulis, hasil penelitian ini sesuai dengan teori yang dinyatakan oleh Notoatmodjo (2007) bahwa semakin banyak informasi yang akurat dan jelas serta dapat dipahamai secara benar maka akan semakin baik pengetahuan tentang pengaruh tindakan cemoteraphy terhadap peningkatan hidup pasien cancer mamae. Tetapi dari hasil penelitian yang didapat responden berpengetahuan kurang mendapat informasi dari tenaga kesehatan. Hal ini disebabkan karena petugas kesehatan yang kurang jelas yaitu secara lisan dan tidak menggunakan media atau alat bantu sehingga susah untuk dipahami.

Berdasarkan hasil penelitian yang disajikan pada tabel 4 menunjukkan bahwa tindakan chemoteraphy terhadap peningkatan hidup pada pasien cancer mamae berdasarkan paritas dengan 32 responden. Mayoritas responden berpengetahuan kurang sebanyak 14 responden $(34,4 \%)$ yaitu multipara. Minoritas berpengetahuan cukup sebanyak 8 responden $(3,1 \%)$ yaitu primipara.

Menurut (Solihin, 2000) bahwa Paritas ibu sangat mempengaruhi tingkat pengetahuan dimana semakin banyak jumlah anak maka akan lebih rentan terhadap penyakit yang mengakibatkan kurangnya kasih sayang, perhatian orang tua terhadap anaknya.

Menurut asumsi penulis, paritas sangat mempengerahui pengetahuan ibu karena semakin tinggi tingkat paritas ibu maka tingkat pengetahuan ibu akan lebih baik.

\section{KESIMPULAN}

1. Hasil penelitian menunjukkan dari tindakan chemoteraphy terhadap peningkatan hidup pada pasien cancer mamae dapat disimpulkan bahwa pengetahuan berkategori kurang.

2. Hasil penelitian menunjukkan dari tindakan chemoteraphy terhadap peningkatan hidup pada pasien cancer mamae dapat disimpulkan bahwa umur berkategori kurang.

3. Hasil penelitian menunjukkan tindakan chemoteraphy terhadap peningkatan hidup pada pasien cancer mamae dapat disimpulkan bahwa sumber informasi berkategori kurang.

\section{DAFTAR PUSTAKA}

Baradero dan dkk. (2008). Asuhan Keperawatan klien gangguan sistem reproduksi dan seksualitas. Jakarta: Salembah Medika.

Corwin, Elizabeth J. (2009). Buku Saku Patofisiologi. Jakarta: EGC.

Cythia dan Deananda. (2009). Pengertian cancer mamae. Jakarta: Rineka Cipta 
Dianandra, R. (2007). Mengenal Seluk Beluk Kanke. Yogyakarta: Katahati.

Dinkes RI. (2009). Buku Ajar Cemotherapy. Jakarta: Trans Info Media

Hawari. (2004). Penyebab cancer mamae. Yogyakarta: Buku Biru.

Notoadmojo, S. (2003). Harapan Hidup Pasien Cancer Mamae. Jakarta: BKKN.

Notoatmodjo, S. (2006). Metodologi Penelitian Kesehatan. Jakarta: Rineka Cipta.

Notoatmodjo, S. (2010). Kesehatan Masyarakat Ilmu Dan Seni. Jakarta: Rineka Cipta.

Hasibuan, O. B. (2018). Pengaruh activity daily livingtraining terhadap kemandirian pasien kanker payudara di murni teguh memorial hospital. Jurnal Ilmiah Keperawatan IMELDA, 4(2), 116-123.

http://jurnal.uimedan.ac.id/index.php/JU RNALKEPERAWATAN/article/view/2 93/296

Noradina, \& Zainofrianto. (2019). Gambaran Perubahan Body Image Pada Wanita Yang Mengalami Ca.Mamae Dengan Tindakan Chemoterphy Di Rumah Sakit Umum Imelda Pekerja Indonesia (Rsu Ipi) Medan. Jurnal Ilmiah Keperawatan Imelda, 5(2), 75-80. https://doi.org/10.2411/JIKEPERAWA TAN.V5I2.312

Social sty Relsen. (2006). Kanker Payudara. Yogyakarta: Fitramaya.

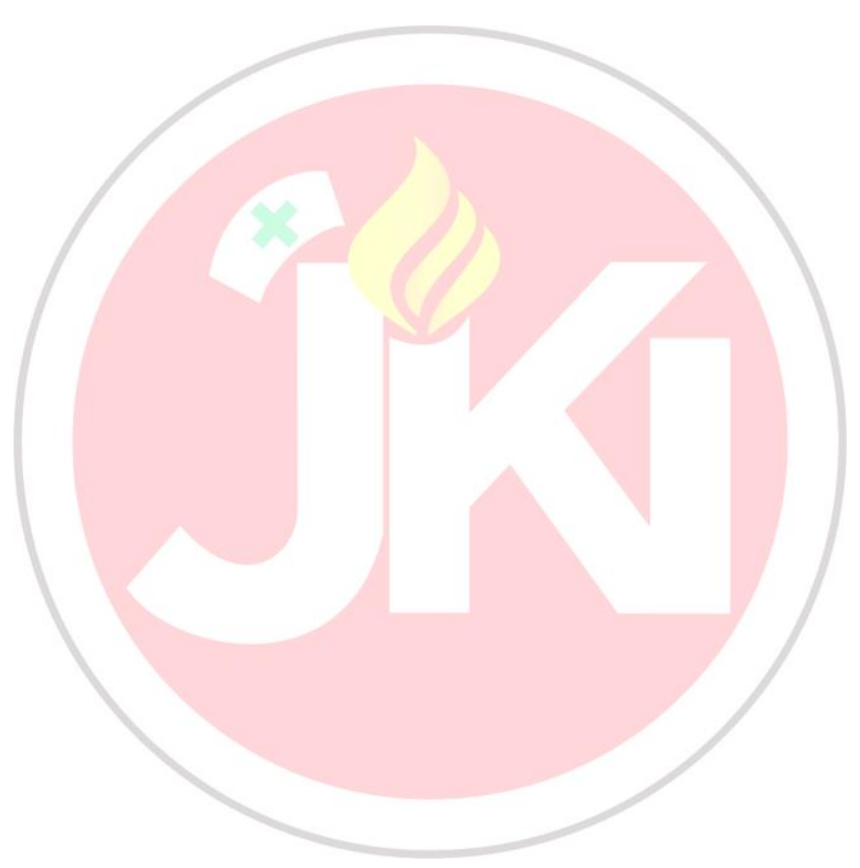

